\begin{tabular}{|l|c|c|}
\hline \multicolumn{2}{|c|}{ DJS Vol. 36 (2013) 17-23 } & $\begin{array}{c}\text { Delta Journal of Science } \\
\text { Available online at } \\
\text { https://djs.journals.ekb.eg/ of scinas. }\end{array}$ \\
\hline $\mathbf{1 9 6 9}$ & \begin{tabular}{c} 
ZOOLOGY \\
\hline Research Article
\end{tabular} & \\
\hline
\end{tabular}

\title{
THE ENCRUSTATION OF THE SPIDER CRAB HYASTENUS HILGENDORFI IN RELATION TO ITS REPRODUCTIVE BIOLOGY IN THE SUEZ CANAL, EGYPT
}

\author{
WAFAA S. SALLAM \\ Department of Marine Science, Suez Canal University, Ismailia, Egypt \\ E-mail: wafaasallam@yahoo.com
}

\begin{abstract}
The encrustation of the spider crab Hyastenus hilgendorfi inhabiting the Suez Canal in relation to its reproductive biology was studied. This species is considered a by-catch in the area of the Suez Canal. It has a negative impact on fishing gear and causes severe damage. Specimens were collected from July 2009 to June 2010. Crabs were sexed and the degree of encrustation was visually assessed. 1054 specimens were collected, of which $569(54.0 \%)$ were males, 363 (34.4\%) non-ovigerous and $122(11.6 \%)$ ovigerous females. $23.7 \%$ (250) had no encrustation while $76.3 \%$ (804) were covered. $49.5 \%$ (398) of encrusted individuals were males; $41.0 \%$ (330) were non-ovigerous females and 9.5\% (76) were ovigerous females. The degree of encrustation varied with carapace width in ovigerous females. Females outnumbered males by 2.9:1 between December and April. Berried females and those with ripe ovaries existed in all seasons except winter. A single reproductive period from June to November was apparent followed by a resting phase between January and March. The size at which 50\% of females were mature was $22.4 \mathrm{~mm}$ CW. Fecundity was found to be related to carapace width. It is concluded that this crab may engage in podding behavior. The successful establishment of this species in the Suez Canal may be related to its fecundity, short larval life span and effective camouflage against predatory fishes. Suggestions for the reduction of the impact of the bycatch of this species on the traditional fishery of the Canal are discussed.
\end{abstract}

Keywords: Encrustation, reproductive biology, Hyastenus hilgendorfi, Suez Canal.

\section{INTRODUCTION}

Spider crabs are distinguished for their habit of masking themselves by placing pieces of foreign substances on their backs and appendages (Wicksten, 1993). Algae, sponges, hydroids, tunicates and other adventitious materials are held in place by the hooked setae that characterize many majid species (Wicksten, 1993; Hartnoll, 1993). Other sessile epibionts, such as cirripeds, bivalves and polychaetes, use majoid carapaces as a substrate for settlement. Finally, mobile organisms, such as amphipods, may live among the attached organisms. The slow movements, absence of burying behavior, and terminal anecdysis contribute to the establishment of a complex and abundant epibiota on many spider crabs (Hartnoll, 1993).

Studies on the reproductive biology of crustaceans provide essential information for understanding their reproductive pattern and strategies. Variations in the sequence of reproductive events are reflected in the diversity of life history pattern necessary for the success of reproduction and growth Therefore, investigations of these aspects are important factors in determining the reproductive potential of a species (Hartnoll, 1985). Information on the reproductive biology of a species such as sex ratio, size at maturity and seasonality of spawning is particularly important if this species has a fishery potential, however, it is equally important for non commercial species when studying the impact those might have on the fishery production of a region (Falk-Petersen, et al. 2010).

The spider crab Hyastenus hilgendorfi (Kossmann, 1880) (Brachyura, Epialtidae) exists in the Suez Canal in huge quantities and is highly distributed around the year in its waters. It is a Red Sea species that migrated into the Suez Canal and established itself in this new environment (Por, 1978), building up large populations (Sallam et al., 2007). Despite flourishing successfully, this crab has no economic significance: it is inedible and has no commercial value or fishery potential. On the other hand, it has a negative impact on fishing gear as enormous numbers of crabs are entangled in nets and cause severe damage (Sallam et al., 2007; Sallam and Wicksten, 2011). Those authors stated that massive occurrence and vast distribution represent a constraint and a threat to successful fishing. Masking behavior of Hyastenus hilgendorfi 
inhabiting the Suez Canal has been studied, however, nothing is known about the relation of this behavior to the reproductive biology of the species. This work aims to deal with some characteristics of $H$. hilgendorf $i$ related with its reproductive biology. The relationship between the reproductive aspects of this species and its encrustation will be examined and discussed. Solution to the reduction of the impact that the bycatch of this species has on the artisanal fishery of the Canal will be suggested.

\section{Materials and Methods}

Specimens of Hyastenus hilgendorfi were monthly collected from July 2009 to June 2010 from Elferdan at $\mathrm{km} 68$ to the south of the Suez Canal. The site was visited in the early morning and crabs were obtained from fishermen's trammel nets with an approximate mesh size of $33.5 \mathrm{~mm}$. They were fixed in $10 \%$ formalin in seawater. Fixed samples were sexed and the numbers of individuals in each sex recorded. Carapace width $(\mathrm{CW})$ was measured by means of Vernier calipers and molting stage was determined. The degree of epibiota coverage on the integument was assessed visually. Each individual was placed in one of 5 step scales: $0 \%, 5-25 \%, 25-50 \%, 50-75 \%$, $75-100 \%$. Diving is prohibited in the Suez Canal, so, it was not possible to view these crabs in situ.

Identification of epibionts was carried out down to species level as much as possible. Females were dissected and the stage of ovarian maturation was noted according to the color of the ovaries (Chu, 1999). For the estimation of fecundity, egg masses were detached from the pleopodal setae, and the eggs were counted manually with a counter under low power (X10) of a stereomicroscope. Egg developmental stage was determined according to the categories listed in Subramoniam (1982).

\section{RESULTS}

\section{Sex ratio:}

A total of collected 1054 specimens were collected, of which $569(54.0 \%)$ were males, $363(34.4 \%)$ non-ovigerous and 122 $(11.6 \%)$ ovigerous females. Females outnumbered males between December and April by 2.9:1 (Figure.1) but males predominated throughout the rest of the year. This variation in sex ratio was significantly different $(\mathrm{X} 2=6.69, \mathrm{P}<0.05)$.

\section{Encrustation with epibionts:}

All individuals were hard shelled. Of the total sample, 23.7\% (250) had no material covering their integuments and 76.3\% (804) were covered with epibionts (Table 1). 49.5\% (398) of encrusted individuals were males; $41.0 \%$ (330) were nonovigerous females and 9.5\% (76) were ovigerous females. The recorded macro-epibionts included the green alga Ulva rigida Linnaeus 1753, the sponge Geodia micropunctata (Issel, 1869), the tubeworm Hydroides elegans (Haswell, 1883), the barnacles Amphibalanus amphitrite (Darwin, 1854) and Balanus eburneus (Gould, 1841), the bivalve Brachidontes variabilis (Krauss, 1848) and the tunicate Styela plicata (Lesueur, 1823). The degree of encrustation varied according to seasons between the different categories of individuals (Figure. 2). Ovigerous females disappeared completely during winter while males and non-ovigerous females were presented in different percentages and degrees of encrustation all year round. Non-encrusted males and non-ovigerous females (with $0 \%$ cover) were highly abundant in spring, as well as fully encrusted ovigerous females (with 100\% cover). Males and non-ovigerous females with full coverage were most common in winter but ovigerous females with $0 \%$ cover were most common in summer. The degree of encrustation varied with carapace width in ovigerous females (Figure.3). Individuals with full coverage fell within both the smallest and the largest ranges $(14-17 \mathrm{~mm}, 26.1-29 \mathrm{~mm} \mathrm{CW})$ respectively while those with bare integuments were most common $(36.4 \%)$ in the smallest size. However, the number of eggs carried by females did not vary significantly with the degree of encrustation on their integuments $(\mathrm{F}=1.291, P=0.280)$ (Table 2$)$.

\section{Incidence of ovigerous females:}

Berried females existed during all seasons except winter when they disappeared completely (Figure.4). They showed their maximum occurrence in summer $(65.6 \%)$ and their minimum in autumn (30.6\%). Non-ovigerous females had their maximum occurrence $(100 \%)$ in winter while their minimal occurrence was observed in summer (34.4\%).

\section{Size at sexual maturity:}

The 407 females examined ranged from 14.5 to $33.6 \mathrm{~mm} \mathrm{CW}$. Of these, 312 were in sexually mature condition. The size at onset of sexual maturity ( $>5 \%$ mature) was within the $20 \mathrm{~mm}$ $\mathrm{CW}$ size. The estimated size for $50 \%$ sexually mature females was $22.4 \mathrm{~mm} \mathrm{CW}$ (Figure 5). The smallest detected ovigerous female had a carapace width of $14.1 \mathrm{~mm}$.

\section{Seasonality of spawning:}

Figure 6 shows the seasonal variations in the percentage of sexually mature females $H$. hilgendorfi. Over $90 \%$ of the population consisted of mature females during a single reproductive period lasting from June to November. This period of reproductive activity was followed by a well-defined resting phase between January and March. Females' gonad condition varied with seasons (Figure. 7). Those with immature ovaries occurred all year round. They occurred in their maximum percentage $(100 \%)$ in winter and their minimum in summer $(21.7 \%)$. Maturing and mature ovaries were observed during autumn and winter only while ovaries in the ripe condition existed in all seasons except winter with their maximum $(27.3 \%)$ in autumn.

\section{Egg development:}

Apparent seasonal variations in the stages of egg development were observed (Figure.8). Eggs at the first stage of development had their minimum in autumn and maximum in spring $(27.3 \%, 44.4 \%)$ respectively while those at the last stage (Stage IV) showed their minimum percentage in summer $(22.6 \%)$ and their maximum in autumn $(72.7 \%)$.

\section{Fecundity and size of female:}

The number of recently extruded eggs carried by ovigerous females ranging in size from 13.0- $27.2 \mathrm{~mm} \mathrm{CW}$ ranged from 1,059- 7,625. Fecundity showed an increase with increasing carapace width (Figure 9). The relationship is expressed by the power function: Egg number=1.243 CW $2.6114(\mathrm{r}=0.678)$.

\section{Discussion}

Hyastenus hilgendorfi was first recorded in the Suez Canal water by Por (1978). This Red Sea species has shown remarkable adaptation to the Canal environment. It was successfully crossed the Canal and reached the Levantine Basin of the Mediterranean (Galil, 2006). This author, established defined species as those that have self-sustaining populations of some duration. The reason for the reproductive success of this species in the Suez Canal habitat is still unknown.

Male $H$. hilgendorfi predominated throughout the seasons except for the months December-April where females outnumbered them by 2.9:1. The same pattern was reported for Schizophrys dahak from the Suez Canal (Morsy, 2007). This period of females' predominance is coincided with their resting phase where over $90 \%$ of the population had immature ovaries. 
This could be explained as a sexual behavior where females aggregate for mating in preparation for the next spawning season. Such aggregating behavior is called podding. Stevens et al. (1992) reported podding in the Pacific species Hyas lyratus Dana, 1851, which involved aggregations of 2000 specimens forming mating groups. Paz Sampedro and González-Gurriarán (2004) concluded that podding in Maja squinado in Galicia, Spain served as a form of protection during molting.

Mating can occur at any time for species with an extended or year-round breeding, although it may be restricted to a certain season for those species with a defined breeding season (Sastry 1983). Male $H$. hilgendorfi dominated during the months when females were brooding. This could be due to their increased breeding access since females tend to be less active during those months. Hiding during egg incubation has been reported for several brachyuran crabs (Henmi, 1989; Stone and O'Clair, 2002).

The present study showed clearly that $H$. hilgendorfi is a seasonal breeder and multiple spawner. The pattern of gonadal maturation is supported by the incidence of ovigerous females and egg development displayed the clear existence of an annual reproductive cycle in which females performed multiple ovipositions within the reproductive season. This trend is common in crustaceans inhabiting the Suez Canal (Sallam, 2000; Morsy, 2007) as well as other areas (Morgan et al., 1983, Rotlant, et al., 2007). Emmerson (1994) stated that breeding periodicity can be controlled by a combination of factors including latitude, temperature, food availability (both adult and larval) and intertidal zonation. The tendency of crabs to release their larvae in a series of successive spawns during the breeding season has been explained as a method of ensuring the widespread of offspring (Cobb and Caddy, 1989). Breeding in tropical crustaceans extends for several months of the year, with pronounced activity during certain months (Pillay and Nair, 1973). An extended breeding season may mean that individuals of a species breed asynchronously, i.e., some are in the earlier stages of maturation while others are already spent (Giese, 1959).

Fecundity of $H$. hilgendorfi ranged between 1,059- 7,625 eggs. Similar results have been reported for the South American spider crab Libidoclaea granaria (Schejter and Spivak, 2005). The fecundity of spider crabs ranges from 180 (Hines, 1982) to 4,000,000 eggs per female (Haynes et al., 1976), and the carapace width $(\mathrm{CW})$ of mature females ranges from 5 (Hines, 1982) to $400 \mathrm{~mm}$ (Haynes et al., 1976). The number of eggs carried by a female $H$. hilgendorfi agreed with the expected fecundity of a relatively small spider crab (20 to $40 \mathrm{~mm} \mathrm{CW}$ ).

The total number of sample increased by $21.8 \%$, i.e. 1054 individuals compared to 865 reported in a previous study (Sallam \& Wicksten, 2011). This progressive rise in the number of individuals reflects the remarkable ability of this Red Sea species to inhabit and adapt to the Canal environment, particularly by achieving successful reproduction.

The encrustation pattern of $H$. hilgendorfi in the Suez Canal did not vary in terms of covering material and seasonality of epibionts than that previously recorded by Sallam and Wicksten (2011). Mating took place during winter when males and non-ovigerous females were completely covered (Sallam and Wicksten 2011). Berke et al. (2006) concluded that the addition of material on the exoskeleton during decorating behavior does not influence fecundity in masking invertebrates but it reduces their mortality risk. The absence of relationship between fecundity of $H$. hilgendorfi and the degree of encrustation implies that camouflage is not the reason behind the increased numbers of this species in the Canal. Drickamer \& Vessey (1982) stated that if a species occupies an area and reproduce there, this means that all its needs are met and the environment is suitable for the development and growth of the offspring, and hence the probabilities for its survival increase, which ensures species continuity. It seems, therefore, that the Canal environment has provided $H$. hilgendorf $i$ with all the requirements needed for its survival, thus facilitating its establishment to a great extent.

In $H$. hilgendorfi, the function of the mask has been reported to serve in avoidance of diurnal predators (Sallam \& Wicksten, 2011). Members of the families Tetradontidae and Balistidae were known as predators of crabs (Stokes, 1980; Bemert \& Ormond, 1981). These coral dwelling fishes are represented in the Suez Canal waters by the pufferfish Lagocephalus spadiceus (Richardson, 1844) and the triggerfish Ballistes carolinesis Gemlin, 1789 (Elmor, 2002). Both species are Red Sea migrants and have been reported in the Canal as nonestablished with rare occurrences (Ben Abdallah et al., 2005). Octopuses or sea turtles, known crab predators, were not found in the area. Although Berke et al. (2006) concluded that camouflaging behavior of majoid crabs reduces their mortality risk; it was not possible to establish whether the heavy encrustation on $H$. hilgendorfi provides an advantage in surviving to reproduction.

All crabs were in the intermolt condition. As many smaller crabs seemed to be covered as larger, older ones. It could be postulated that the oldest females and males might be the most heavily encrusted or decorated because of the terminal anecdysis. There is no evidence that heavily covered males are more or less successful in mating than smaller, less encrusted ones. Encrusting material particularly ascidians, barnacles, and tube worms have been found on concrete blocks, rocks, piers, buoys in the Canal as well as other crabs. They showed apparent seasonality with high rate of larval settlement during summer (Elkhawass, 2006; Morsy, 2007 ; Sharaf, 2009).

Spider crabs tend to have short larval life spans, ranging from nine to 15 days (Gonzalez- Gordillo \& Rodríguez, 2001; Santana et al., 2004; Kornienko \& Korn, 2006) as well as a short interval between the hatching of one batch of eggs and the laying of the next (Jones \& Hartnoll, 1997). De Kergariou, (1971) stated that the rate of larval development of Maia squinado in Bretagne varied with seawater temperature, being faster at higher seawater temperatures. It could therefore be proposed that $H$. hilgendorfi larvae develop rapidly in the Suez Canal waters. Their short residency in the plankton helps increase their survival rate. The short larval life span, in addition to the scarcity of predators could be reasons for the apparent flourishing of this species in the Suez Canal.

The entanglement of these crabs has caused severe problems in the traditional fishery of the Canal. Large by-catches cause extra work for the fishermen, damage their gear and ruin the catch. A similar problem has been reported for the red king crab Paralithoides camtschaticus in northern Norway (Godøy et al., 2003). The authors suggested the use of the "norselmounted" nets that float above the seabed which enable crabs to pass beneath them without becoming entangled. They indicated that the gear configuration has been capable of reducing the bycatch to an acceptable level. Raising awareness of the fishermen working in the Suez Canal for not returning alive ovigerous $H$. hilgendorfi females to the water could eventually lead to the reduction of the bycatch. The study also proposes invitation of businessmen in the farmed fish industry to consider investing in these crabs. They could be exploited by using their meals as a protein additive to the fish feed. This would raise the palatability of the feed and increases the food conversion rate.

\section{References}


Bemert, G. and Ormond, R. (1981) Red Sea coral reefs, Kegan Paul International, Ondon, 192 pages.

Ben Abdallah, A.R.; Alturky, A. and Fituri, A. (2005) Records of exotic fishes in the Libyan coast. Journal of Libyan Marine Science 10, 1-18.

Berke, S. K.; Miller, M. and Woodin. S. A. (2006) Modeling the energy-mortality trade - offs of invertebrates decorating behavior. Evolutionary Ecology Research 8, 1409- 1425.

Chu, K.H. (1999) Morphometric analysis and reproductive biology of the crab Charybdis affinis (Decapoda, Brachyura, Portunidae) from the Zhujiang Estuary, China. Crustaceana, 72, 647-657.

Cobb S.J. and Caddy J.F. (1989) The population biology of decapods. In Caddy J.F. (ed). Marine Invertebrate Fisheries: Their Assessment and Management. New York: John Wiley and Sons, New York, NY, pp. 327-374.

De Kergariou, G. (1971) L'araignée de mer, Maia squinado L., sur le littoral de Bretagne. Science et Pêche, Bulletin d'Institute des Pêches maritimes, 205, 11-19.

Drickamer, L.C. and Vessey, S.H. (1982) Animal Behavior, Concepts, Processes and Methods, Willard Grant Press. Boston.

Elkhawass, E.A. (2006) Acorn barnacles in lake Timsah, the effect of environmental factors on their growth and distribution. MSc thesis, Suez Canal University, Ismailia, Egypt.

Elmor, M.E. (2002) Ecological and biological studies on the juvenile commercial fishes from Port Said coast. $\mathrm{PhD}$ thesis, Suez Canal University, Ismailia, Egypt.

Emmerson, W.D. (1994) Seasonal breeding cycles and sex ratios of eight species of crabs from Mgazana, a mangrove estuary in Transkei, Southern Africa. Journal of Crustacean Biology Vol. 14 (3), 568-578.

Falk-Petersen, J., Renaud, P., and Anisimova, N. (2010) Establishment and ecosystem effects of the alien invasive red king crab (Paralithodes camtschaticus) in the Barents Sea - a review - ICES Journal of Marine Science, doi:10.1093/icesjms/fsq192, pp 1-10.

Galil B.S. (2006) A rare record of Hyastenus hilgendorfi (Crustacea: Decapoda: Majidae) from the Levant. Aquatic Invasions 1(4), 284-285.

Giese, A.C. (1959) Comparative physiology: annual reproductive cycles of marine invertebrates. Annual Review of Physiology 21, 547-576.

González- Gordillo. J.I. and Rodríguez, A. (2001) The complete larval development of the spider crab Macropodia parva (Crustacea, Decapoda, Majidae) from laboratory culture. Invertebrate Reproduction and Development 39:2, 135-142.

Godøy, H., Furevik, D. and Løkkeborg, S. (2003) Reduced bycatch of red king crab (Paralithoides camtschaticus) in the gillnet fishery for cod (Gadus morhua) in northern Norway. Fisheries Research 62, 377-384.
Hartnoll, R.G. (1985) Growth, sexual maturity and reproductive output. In Wenner A. M. (ed.) Factors in adult growth. A. A. Balkema, Rotterdam, Boston, pp 101-128

Hartnoll, R.G. (1993) The epibiota of the spider crabs. Proceedings of the Fourth Colloquium Crustacea Decapoda Mediterranea. Bios (Macedonia, Greece), Scientific Annals of the School of Biology 1, 163-176.

Henmi, Y. (1989) Reproductive ecology of three ocypodid crabs. II. Incubation sites and egg mortality. Ecological Research 4, 261-269.

Hines, A.H. (1982) Allometric constrains and variables of reproductive effort in brachyuran crabs. Marine Biology 69, 309-320.

Haynes, E., Karinen, J. F., Watson, J. and Hopson, D. J. (1976) Relation in number of eggs and egg length to carapace width in the brachyuran crabs Chionoecetes bairdi and C. opilio from the Gulf of St. Lawrence. Journal of the Fisheries Research Board of Canada 33, 2592-2595.

Jones, D.R. and Hartnoll, R.G. (1997) Mate selection and mating behavior in spider crabs. Estuarine, Coastal and Shelf Science 44, 185-193.

Kornienko, E.S. and Korn, O.M. (2006) The larvae of the spider crab Pisoides bidentatus (A. Milne-Edwards, 1873) (Decapoda: Majoidea: Pisidae) reared under laboratory conditions. Journal of Plankton Research. Vol. 29, Issue 7. Pp. 605-617.

Morgan, S.G., Goy, J.W. and Costlow, J.D.Jr. (1983) Mutiple ovipositions from single matings in the mud crab Rhithropanopeus harisii. Journal of Crustacean Biology 34(4), 542-547.

Morsy N.K. (2007) Studies on fishery and biology of the Brachyuran crabs of the Suez Canal. PhD thesis, Suez Canal University, Ismailia, Egypt.

Paz Sampedro, M. And González-Gurriarán, E. (2004) Aggregating behavior of the spider crab Maja squinado in shallow waters. Journal of Crustacean Biology 24(1), 168177.

Pillay, K.K. and Nair, N.B. (1973) Observations on the biochemical changes in gonads and other organs of Uca annulipes, Portunus pelagicus and Metapenaeus affinis (Decapoda: Crustacea) during the reproductive cycle. Marine Biology 18, 167-198.

Por, F.D. (1978) Lessepsian Migration, The Influx of Red Sea Biota into the Mediterranean by way of the Suez Canal. Springler-Verlag, Berlin.

Rotlant, G, González-Gurriarán, E, Fernndez, L, Benhalima, K. and Ribes, E. (2007) Ovarian maturation of the multispawning spider crab Maja brachydactyla (Decapoda: Majidae) with special reference to yolk formation. Marine Biology 152, 383-394.

Sallam, W.S. (2000) Studies on the biology of mantis shrimps in the Suez Canal. PhD thesis, Suez Canal University, Ismailia, Egypt. 
Sallam, W.S. and Wicksten, M.K. (2011) Hyastenus hilgendorfi (De Man, 1887) (Brachyura: Pisidae): A heavily encrusted decorator crab inhabiting the Suez Canal. Crustaceana 84(2), 203-219.

Sallam, W.S., Madkour, F.F. and Wicksten, M.K. (2007) Masking behavior of the spider crab Hyastenus hilgendorfi (De Man, 1887) (Brachyura, Majidae) from the Suez Canal, Egypt. Crustaceana 80 (2), 235-245.

Santana, W., Pohle, P. and Marques, F. (2004) Larval development of Apiomithrax violaceus (A. Milne Edwards, 1868) (Decapoda: Brachyura: Majoidea: Pisidae) reared in laboratory conditions, and a review of larval characters of Pisidae. Journal of Natural History, Vol. 38, Issue 14, 2004, Pages 1773 - 1797.

Sastry, A.N. (1983) Ecological aspects of reproduction. In, Bliss D.E. (ed) The Biology of Crustacea. Vol. 8. Environmental Adaptations. Academic Press. Pages 179-270.

Schejter, L. and Spivak, E. (2005) Morphometry, sexual maturity, fecundity and epibiosis of the South American spider crab Libidoclaea granaria (Brachyura: Majoidea). Journal of the Marine Biological Association of the United Kingdom 85, 857-863.

Sharaf. G.M.A. (2009) Ecological and biological studies on ascidians (Urochordata: Tunicata) in the Suez Canal. PhD thesis, Suez Canal University, Ismailia, Egypt.

Stevens, B.G.; Donaldson, W.E. and Haaga, J.A. (1992) First observations of podding behavior for the Pacific lyre crab Hyas lyratus (Decapoda: Majida). Journal of Crustacean Biology 12, 193- 195.

Stokes, F. J. (1980) Hand guide to the coral reef fishes of the Carribean. Lippincot and Crowell Publishers. New York.

Stone, R.P. and O'Clair, C.E. (2002) Behavior of females Dungeness crab Cancer magister in a glacial Southeast Alaska estuary: Homing, brooding and site fidelity, seasonal movements and habitat use Journal of Crustacean Biology 22(2), 481-492.

Table 1. Hyastenus hilgendorf (De Man), numbers and percentages of the different categories of covered individuals

\begin{tabular}{|c|c|c|c|c|c|c|c|}
\hline \multirow{3}{*}{ Months } & \multicolumn{2}{|c|}{ Number of individuals } & \multicolumn{4}{|c|}{ Masked indiriduals } & \multirow[b]{2}{*}{ Total } \\
\hline & $\begin{array}{l}\text { Iales Non- } \\
\text { ovigerous }\end{array}$ & $\begin{array}{l}\text { Oxigerous Total } \\
\text { is females }\end{array}$ & Males & & $\begin{array}{l}\text { rigerous } \\
\text { sales }\end{array}$ & $\begin{array}{c}\text { Origerous } \\
\text { females }\end{array}$ & \\
\hline & & & $\mathrm{N} \%$ & $\mathrm{~N}$ & $\%$ & N $\%$ & N $\%$ \\
\hline
\end{tabular}

\begin{tabular}{|c|c|c|c|c|c|c|c|c|c|}
\hline Jul. 09 & 69 & 4 & 9 & 82 & 3855.1 & 0 & 0.0 & 111.1 & 3947.6 \\
\hline Aug. & 55 & 13 & 22 & 90 & $42 \quad 76.4$ & 12 & 92.3 & 731.8 & 6167.8 \\
\hline ep. & 70 & 6 & 17 & 93 & $52 \quad 74.3$ & 4 & 66.6 & 1023.5 & 6671 \\
\hline t. & 41 & 5 & 11 & 57 & 3782.2 & 4 & 80.0 & $\begin{array}{ll}8 & 72.7\end{array}$ & 86.0 \\
\hline vv. & 97 & 66 & 11 & 174 & 9698 & 64 & 96.9 & 11100 & 98.3 \\
\hline & 10 & 12 & 0 & 22 & 770.0 & 11 & 91.7 & 0 & \\
\hline in. 10 & 16 & 46 & 0 & 62 & 1168.8 & 40 & 87.0 & 0 & \\
\hline & 57 & 78 & 0 & 135 & 2035.1 & 77 & 97.5 & 0 & 71.8 \\
\hline lar. & 39 & 84 & 0 & 123 & 3794.9 & 82 & 97.6 & 0 & 1996.7 \\
\hline & 62 & 37 & 32 & 131 & 4775.8 & 31 & 83.8 & 2784.4 & 80 \\
\hline lay & 26 & 5 & 10 & 41 & 623.1 & 1 & 20.0 & $6 \quad 60.0$ & 1331 \\
\hline & 27 & 7 & 10 & 44 & $\begin{array}{ll}5 & 18.5\end{array}$ & 3 & 42.8 & $6 \quad 60.0$ & 1431 \\
\hline
\end{tabular}

Subramoniam, T. (1982) Determination of reproductive of periodicity in the intertidal mole crab Emerita asiatjca. In Sillas E. G. (ed) Manual of Research Methods for Marine Invertebrate Reproduction. CMFRI Special publication, Number 9. Diocesan Press, Madras, India, pp.167.

Wicksten, M.K. (1993) Review and a model of decorating behavior in spider crabs (Decapoda, Brachyura, Majidae). Crustaceana 64 (3), 314325.

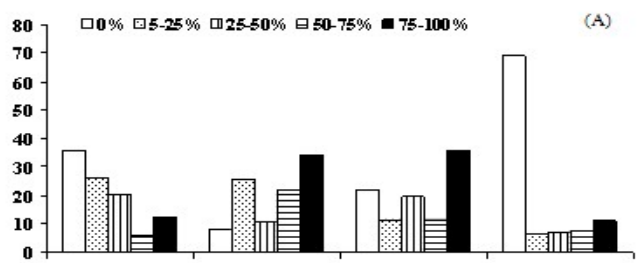

Table 2. Mean number of eggs in the different degrees of coverage for ovigerous females Hyastenus hilgendorfi.

\begin{tabular}{|c|c|c|}
\hline $\begin{array}{c}\text { Degree of } \\
\text { coverage }\end{array}$ & $\begin{array}{c}\text { Mean number } \\
\text { of eggs }\end{array}$ & N \\
\hline & & \\
$0-5 \%$ & 3447.9 & 28 \\
$5-25 \%$ & 4336.8 & 21 \\
$25-50 \%$ & 3271.3 & 20 \\
$50-75 \%$ & 3944.5 & 20 \\
$75-100 \%$ & 3734.5 & 33 \\
\hline
\end{tabular}

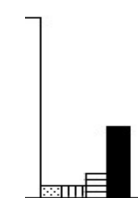

$\mathrm{N}=$ number of individuals in each category.

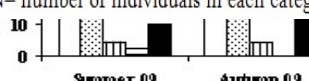

Minter 10
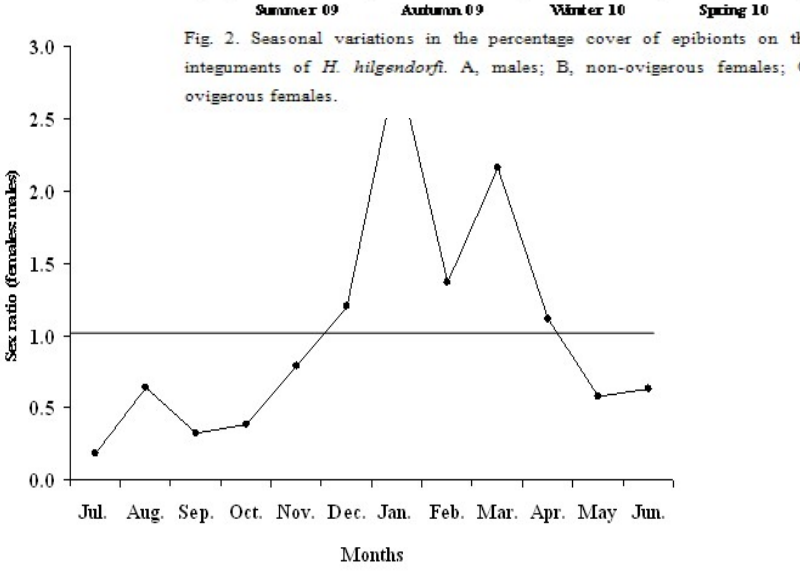

Fig.1. Monthly changes in the sex ratio (females: males) of $H$. hilgendorfi. 


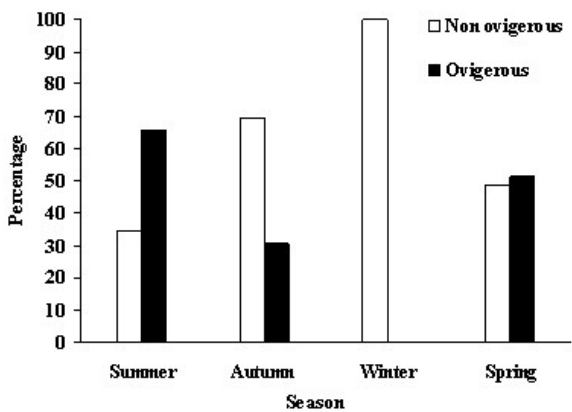

Fig. 4. Seasonal variations in the occurrence of ovigerous and non-ovigeous female H. hilgendorfi.

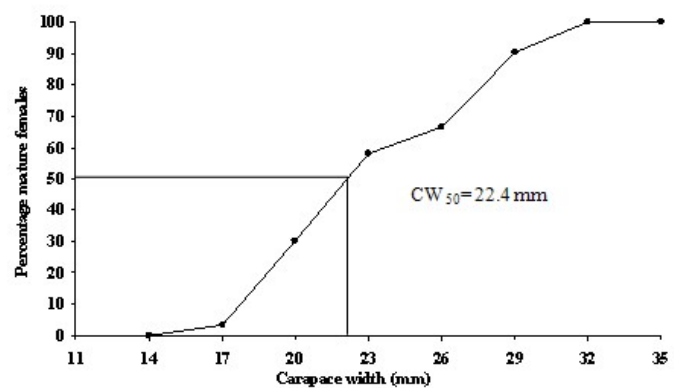

Fig. 5. Percentage maturity of female H. hilgendorfi in relation to carapace width

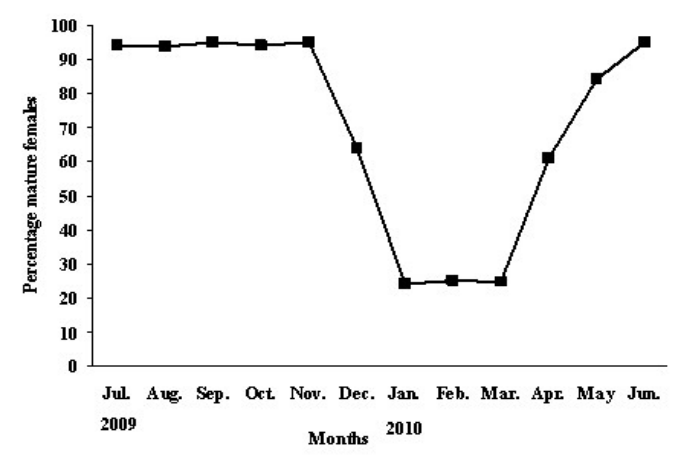

Fig. 6. Seasonality of spawning of females H. hilgendorfi.

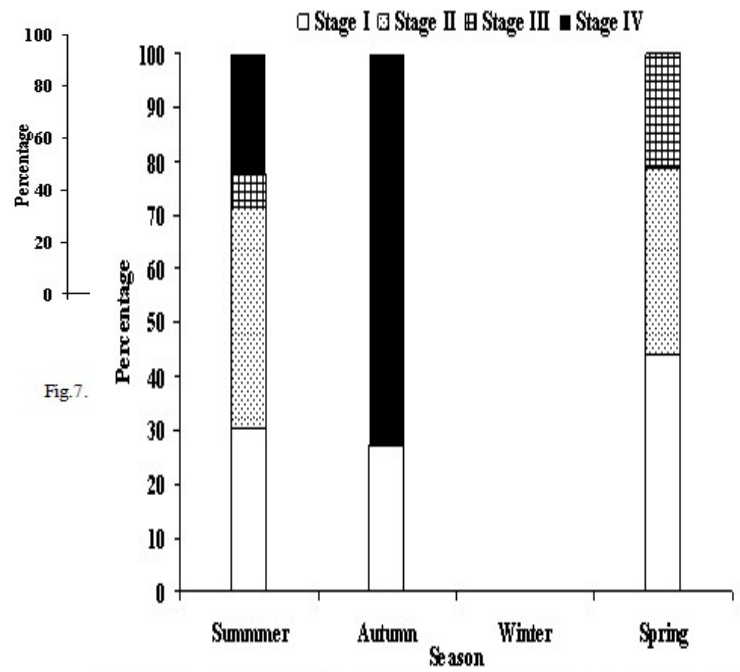

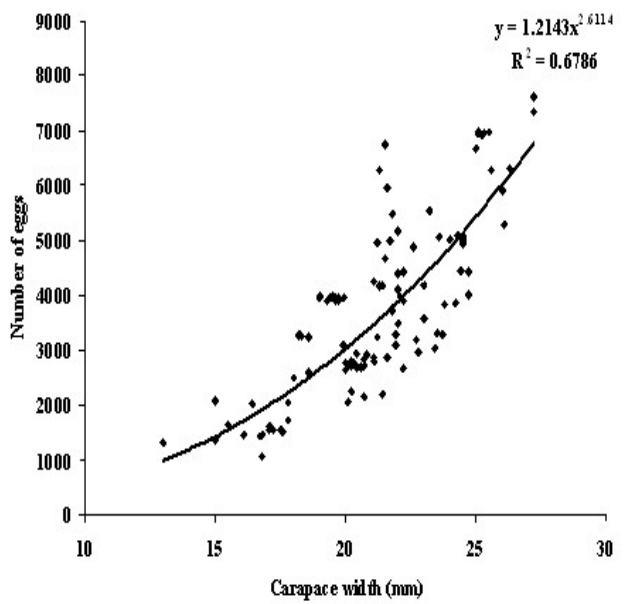

Fig. 9. Relationship between carapace width and number of eggs infemale $H$. hilgendorfi.

Fig. 8. Seasonal changes in the stages of egg development in females $H$. hilgendorfi. 